\title{
The Morpho-Genetic Estimation of Drought Stress in Sunflower Seedlings under Laboratory Conditions
}

Uzma Ayaz $^{*}$, Sanam Bashir ${ }^{1}$, Shahid Iqbal Awan², Muhammad Ilyas², Muhammad Fareed Khan ${ }^{3}$, Hameed-ur-Rehman $^{4}$

${ }^{1}$ Msc (Hons.) Department of Plant Breeding and Molecular Genetics, The University of Poonch Rawalakot, Pakistan, Azad Jammu \& Kashmir, Pakistan.

${ }^{2}$ Assistant Professor Department of Plant Breeding and Molecular Genetics The University of Poonch Rawalakot, Pakistan, Azad Jammu \& Kashmir, Pakistan.

${ }^{3}$ Dean Faculty of Management Sciences, the University of Poonch Rawalakot, Pakistan Azad Jammu \& Kashmir.

${ }^{4} \mathrm{PhD}$. Scholar Department of Zoology, Kohat University of Science \& Technology.

Corresponding Author: Uzma Ayaz, Msc (Hons.) Department of Plant Breeding and Molecular Genetics, The University of Poonch Rawalakot, Pakistan, Azad Jammu \& Kashmir, Pakistan.

Received date: November 16, 2020; Accepted date: January 13, 2021; Published date: January 18, 2021

Citation: U Ayaz, S Bashir, Shahid I Awan, M Ilyas, Muhammad F Khan, Hameed U Rehman. (2021) The Morpho-Genetic Estimation of Drought Stress in Sunflower Seedlings under Laboratory Conditions. Biomedical Research and Clinical Reviews. 3(1); DOI: 10.31579/2692-9406/034

Copyright: (c) 2021 Uzma Ayaz, This is an open-access article distributed under the terms of the Creative Commons Attribution License, which permits unrestricted use, distribution, and reproduction in any medium, provided the original author and source are credited.

\section{Abstract}

Drought stress directly affects the growth along with productivity of plants by altering plant water status. The present study was carried out to characterize the genetic variability for seedling and morpho-physiological parameters in different sunflower genotypes under water stressed conditions. A total twenty seven genotypes including two hybrids, eight advanced lines and seventeen accessions of sunflower (Helianthus annuus L.) were tested against drought stress at seedling stages by applying Polyethylene glycol (PEG). Significant means were calculated among traits using analysis of variance (ANOVA) whereas, correlation and principle component analysis also confirmed that germination percentage, root length, shoot length, chlorophyll content, stomatal frequency are positively linked with each other hence, these traits were responsible for most of variation among genotypes. The cluster analysis showed that genotypes Ausun, line-1, line-2, line-3, 17578, 17570, line-6, line-7 and 17562 are more diverse among all the genotypes.

Key words: morphological; genetic; sunflower; genotypes; drought stress

\section{Introduction}

Sunflower (Helianthus annuus L.) has emerged as an economically important crop of Pakistan. Water shortage is becoming a key problem for sustainable agriculture in Pakistan. The reduced precipitation, along with high evapo-transpiration is expected to subject natural agricultural vegetation to a great possibility of severe and delayed water stress with every passing year (Shamim et al., 2013).

Crop responses toward drought stresses involve processes modulated by water shortage at morphological, anatomical, cellular and molecular levels. The changes which occur in the whole plant organs in response to water stress reduce plant photosynthesis resulting in grain yield decline. It would be very useful to develop effectual strategies to reduce drought stress damage in crop plants. (Tardieu and Tuberosa, 2010).

Several morphological and physiological characters affected by drought stress include reduced leaf area, plant height, root length, head diameter, yield per plant, and plant biomass as well as photosynthetic rate. Severe drought stress may possibly result in arresting of photosynthesis, metabolic disturbance and also plant death. (Kumar et al., 2011).

High molecular weight Polyethylene glycol (PEG) has been used to stimulate drought stress in plants. Polyethylene glycol (PEG) of high molecular weight is a non-penetrating osmotic agent lowering the water potential in a way that is similar to soil drying. The ability of Polyethylene glycol of becoming negative water potential can be used as a mean to assume plant tissue response by drought stress. (Yosephine et al., 2013).

The present study was carried out to characterize the genetic variability for seedling and morpho-physio parameters in different sunflower genotypes under water stressed condition and to find favourable tolerant genotypes under various levels of water stress.

\section{Materials and methods}

\section{Experimental Area:}

The experiment was carried out at the laboratory of Plant Breeding and Molecular Genetics, Faculty of Agriculture, University of Poonch Rawalakot.

\section{Seed Sample:}

The material was comprised of twenty seven genotypes of sunflower (Helianthus annuus L.) acquired from Oil Seed Research Program (NARC) Islamabad.

\section{Experimental Design:}

The experiment was laid out in $2 \times 2$ factorial completely randomized design with three replications for each experimental unit. 


\section{Laboratory Conditions:}

Temperature: $\left(25 \pm 3^{\circ} \mathrm{C}\right)$.

\section{Drought Stimulator:}

Polyethylene glycol with a molecular weight of 6000 (PEG-4000) was used as a drought stimulator.

\section{Duration:}

The experiment was completed after 30 days of planting.

\section{Studied Traits:}

1) Germination Percentage: Number of seeds germinated counted daily and data was recorded for 14 days.

Germination $\%=(\mathrm{n} / \mathrm{N}) \times 100$ where $\mathrm{n}$ : number of seeds germinated, N: total number of seed in each pot.

2) Shoot length: Shoot length of five plants from every pot was measured in $\mathrm{cm}$ and their mean was calculated.

3) Root length: Root length of five plants from every pot was measured in $\mathrm{cm}$ and their mean was calculated.

4) Root \& shoot fresh weight: Root and Shoot of each plant was separated and their fresh weight was determined separately with the help of a digital electrical balance.

5) Root dry weight: Root of each plant was dried in an oven at $60^{\circ} \mathrm{C}$ for 24 hours and their dry weight was measured.

6) Shoot dry weight: Shoot of each plant was dried in an oven at $60^{\circ} \mathrm{C}$ for 24 hours and their dry weight was measured.

8) Root dry weight: Root of each plant was dried in an oven at $60^{\circ} \mathrm{C}$ for 24 hours and their dry weight was measured.

8) Stomatal frequency: The leaf stripes were used for counting the stomata at Low power microscopic field (10x) to investigate stomatal frequency.

9) Chlorophyll contents: The chlorophyll concentration was determined by the method of Arnon (1949).

Chlorophyll content $=8.0 \times$ O. D at $663 \mathrm{~nm}+20.2 \times \mathrm{O}$. D at $645 \mathrm{~nm}$

\section{Statistical Analysis:}

The data was analyzed to calculate phenotypic correlation coefficients between the studied traits (Snedecor, 1956). Simple statistics and numerical taxonomic techniques were utilized for cluster and principle component analysis (Sneath and Sokal, 1973) with the help of computer software Statistica, Past (Hammer et al. 2001) and SPSS 20. Cluster analysis was conducted on the basis of average distance of $\mathrm{k}$ means.

\section{Results and discussions:}

\section{Cluster Analysis}

Drought is the main cause of differences between mean yield and potential yield, yield variations from year to year and therefore of yield instability. Cluster analysis was carried to group the sunflower genotypes. The tree diagram based on 27 sunflower genotypes was displayed in Figure 1. The figure indicated four main clusters at linkage distance 7.5. The clusters were named as cluster I, cluster II and Cluster III and Cluster IV. Cluster I contain only one genotype Ausun. Cluster II was further divided into two sub-clusters IIa and IIb. Sub-cluster IIa comprised of four genotypes i.e. 17575, 17577, 17555 and 17573. Sub-cluster IIb consisted of four genotypes line-3, line-2, line-4 and line-5. Among these genotypes Line- 3 and line- 2 was an outlier and showed diversity. The line- 4 and line-5 are at the same linkage distance and show no diversity. Cluster III was further classified into two sub-clusters III a and III b and III c. Sub-cluster III a consisted of three genotypes 17578 , line- 8 and 17580. Among these three genotypes 17578 was an outlier and showed diversity while line- 8 and 17580 were at the same linkage distance and are closely related with each other. Sub group III (b) contain 17570, 17559 and 17572. In this group 17570 was an outlier and 17559,17572 were at the same linkage distance and show no variation. Sub cluster III c contained three genotypes i.e. line-1, 17557 and 17558. In this group 17557,17558 were at the same linkage distance, while line-1 was an outlier. The Cluster IV was subdivided into two sub groups IV (a) and IV (b). The first group consisted of four genotypes line-7, line-6, 17560, and 17561 whereas; group two consisted of five genotypes 17562, 17568, 17581, 17587 and Hysun-33. Among all twenty seven genotypes i.e. Ausun, line-3, line-2, and 17578, 17570, line-1, line-7, line-6 and 17562 showed more diversity as compared to $17575,17577,17555,17573$, , line4, line-5, line-8 17559, 17572,17560, 17561, 17568, 17581, 17587 and Hysun-33 Nadeem et al. 2011, Abdi et al. 2012 and Khamsee et al. 2012 support our present findings.

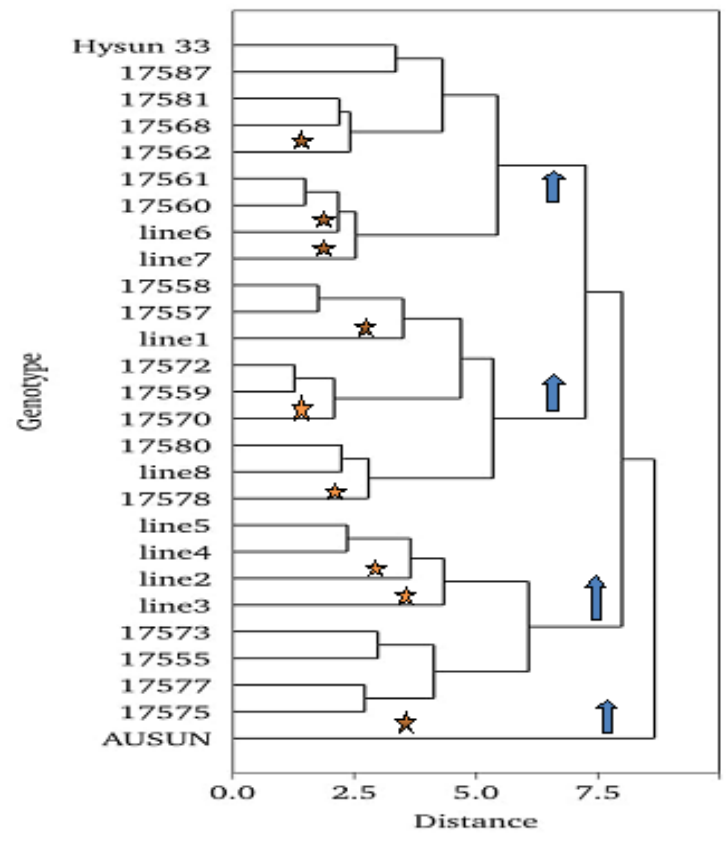

Figure 1: Dendogram based on Euclidean distance in sunflower Genotypes 


\begin{tabular}{|l|l|l|ll|l|}
\hline S.No & Genotype & Source & S.No & Genotype & Source \\
1 & Ausun & NARC & 15 & 17561 & NARC \\
2 & Line 1 & NARC & 16 & 17562 & NARC \\
\hline 3 & Line 2 & NARC & 17 & 17568 & NARC \\
\hline 4 & Line 3 & NARC & 18 & 17570 & NARC \\
\hline 5 & Line 4 & NARC & 19 & 17572 & NARC \\
6 & Line 5 & NARC & 20 & 17573 & NARC \\
7 & Line 6 & NARC & 21 & 17575 & NARC \\
8 & Line 7 & NARC & 22 & 17577 & NARC \\
\hline 9 & Line 8 & NARC & 23 & 17578 & NARC \\
\hline 10 & 17555 & NARC & 24 & 17580 & NARC \\
11 & 17557 & NARC & 25 & 17581 & NARC \\
12 & 17558 & NARC & 26 & 17587 & NARC \\
\hline 13 & 17559 & NARC & 27 & Hysun-33 & NARC \\
\hline 14 & 17560 & NARC & \multicolumn{5}{|l}{} \\
\hline
\end{tabular}

Table 1: List of Twenty Seven Sunflower (Helianthus annuus L.) Genotypes

\section{Correlation studies:}

Correlation and principle component analysis showed that germination percentage, root length, shoot length, chlorophyll content, stomatal frequency have significant relationship with each other; hence these traits were responsible for most of variation among genotypes . Table. 2

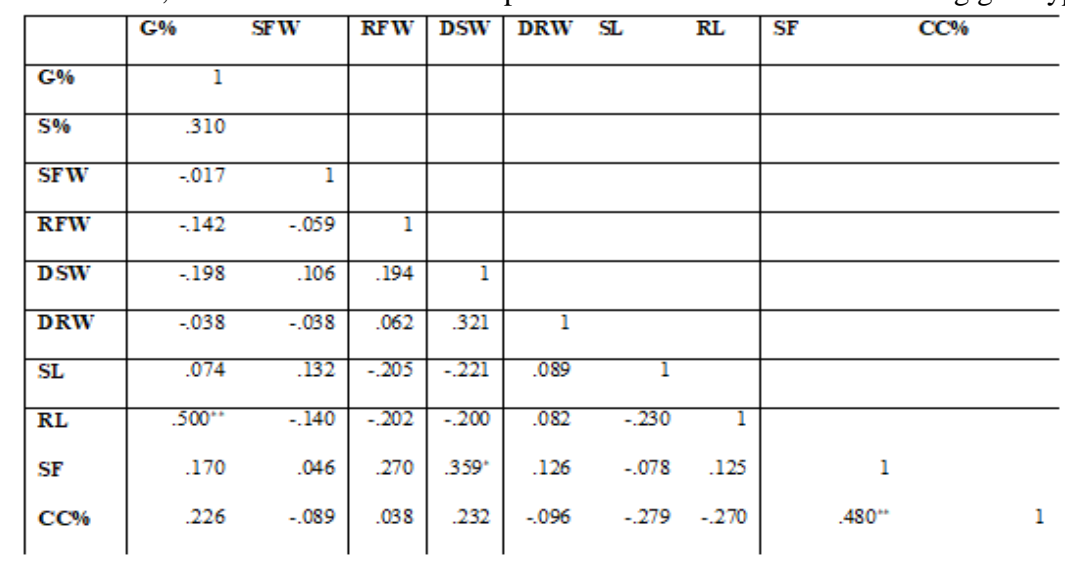

Table 2: Simple correlation coefficients for morpho-physiological traits in 27 Sunflower Genotypes

\section{Divergence of Genotypes on Biplot:}

Biplot verified Ausun, line-4, line 2, line 3, 17587, 17578, 17580, line-8 and 17557 were diverse among all the genotypes. Figure 2. The quantification of genetic diversity by Principle component analysis made it possible to select genetically diverse parents for hybrid production. Genetic diversity is one of the helpful tool to select appropriate genotypes/lines for hybridization (Xia et al., 2005).

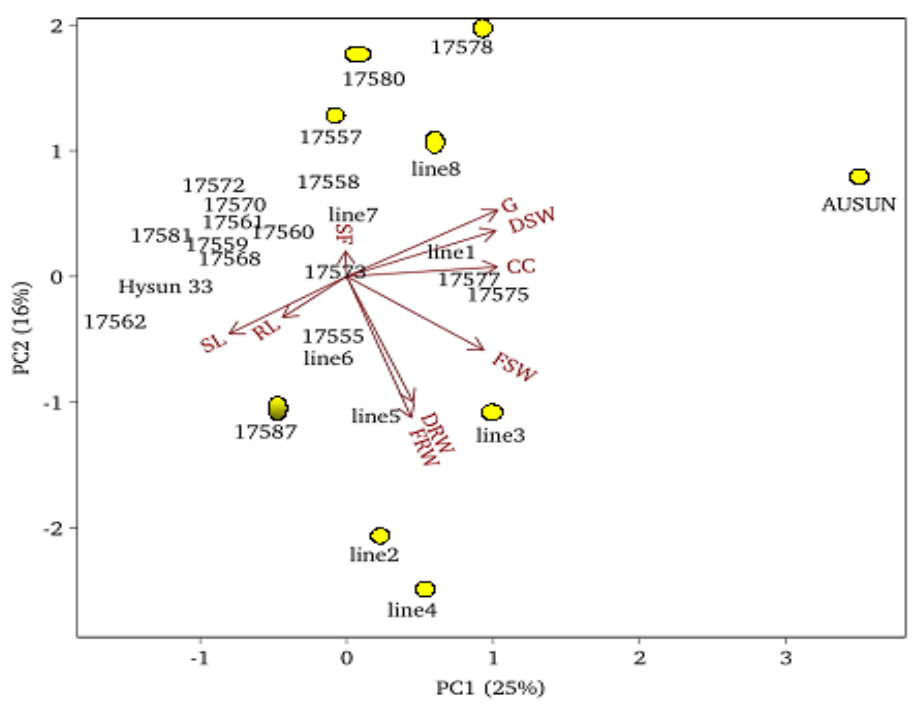

Figure 2: Scatter plot diagram in 27 sunflower Genotypes 


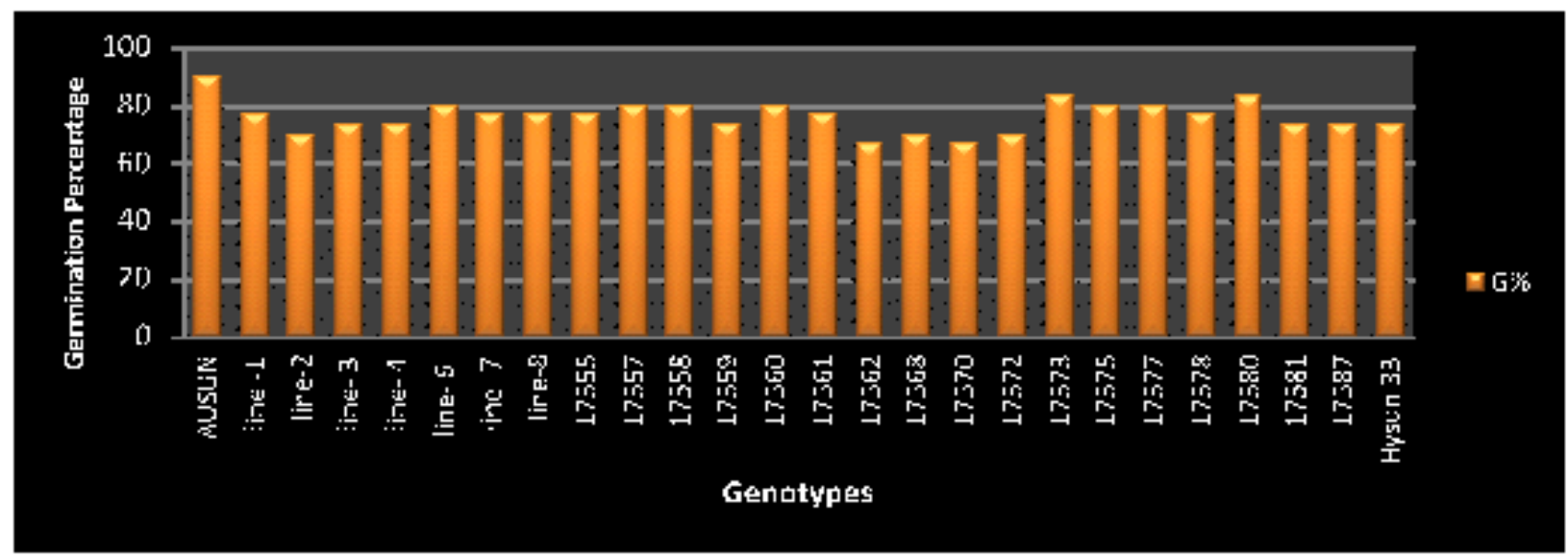

Figure 3: Germination Percentage in 27 Sunflower Genotypes under Drought stress

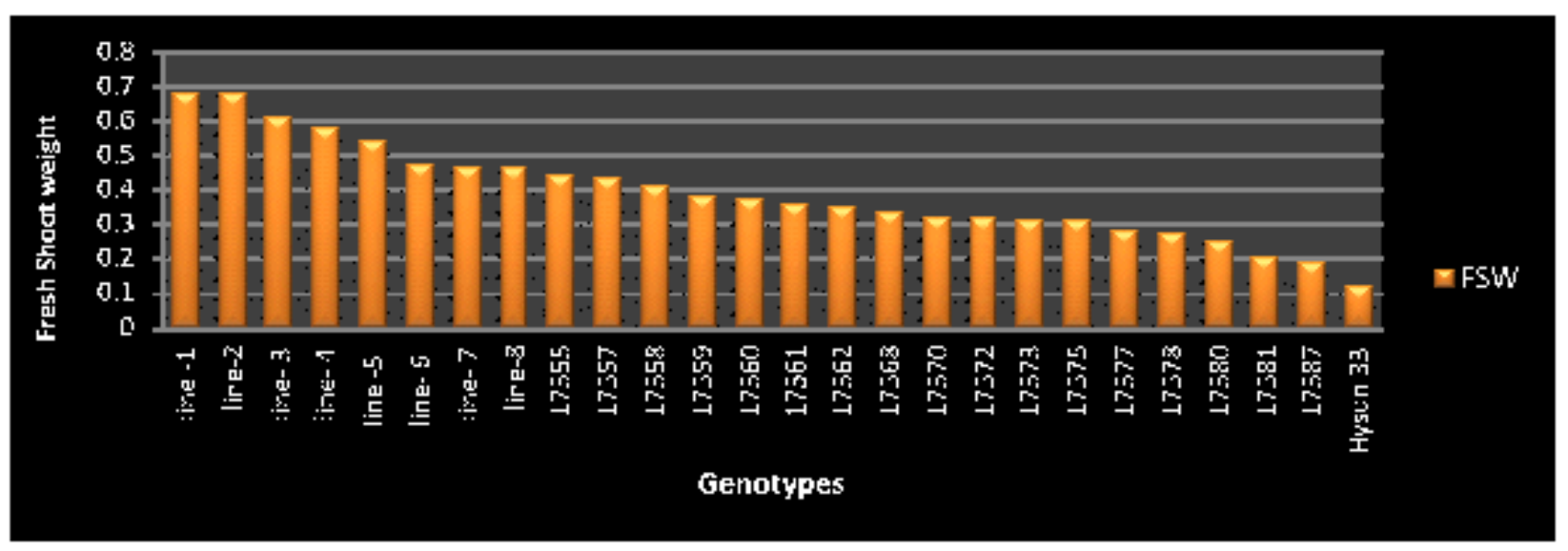

Figure 4: Fresh Shoot weight in 27 Sunflower Genotypes under Drought stress

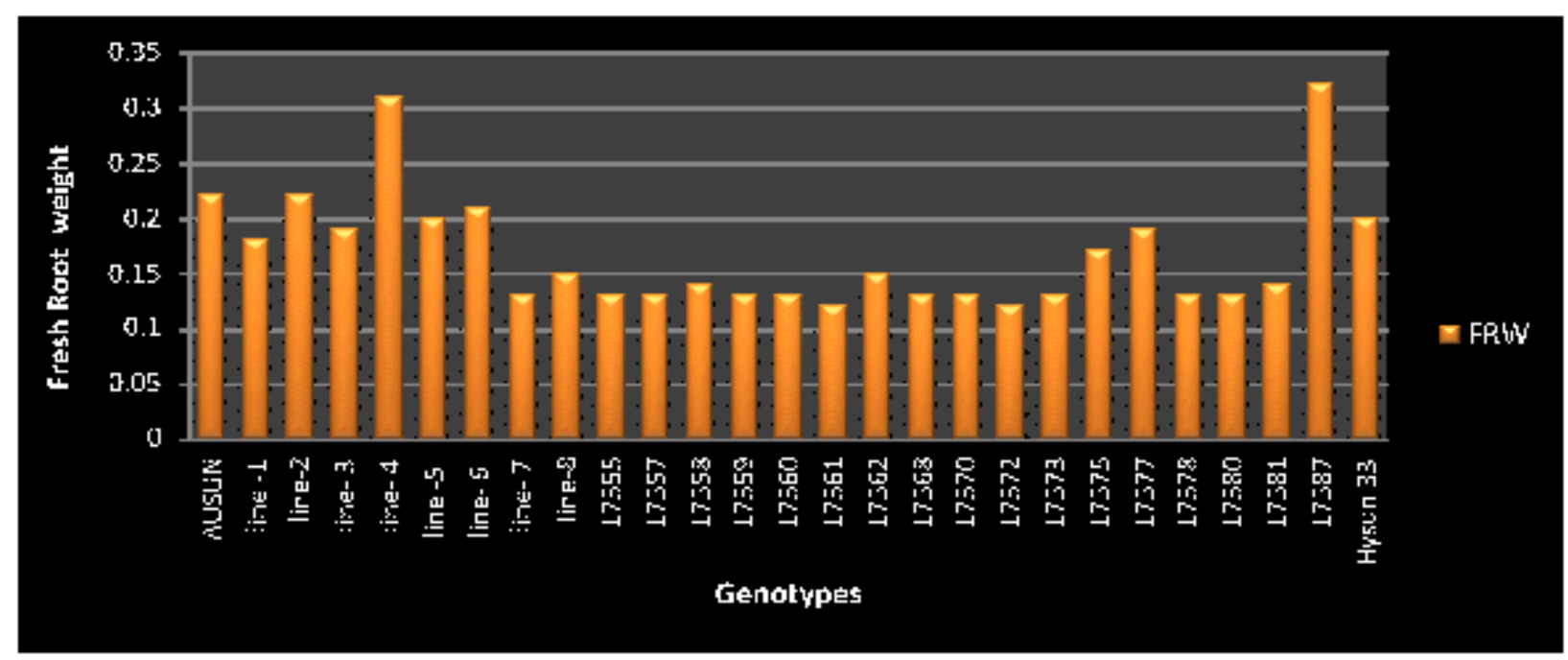

Figure 5: Fresh Root weight in 27 Sunflower Genotypes under Drought Stress 


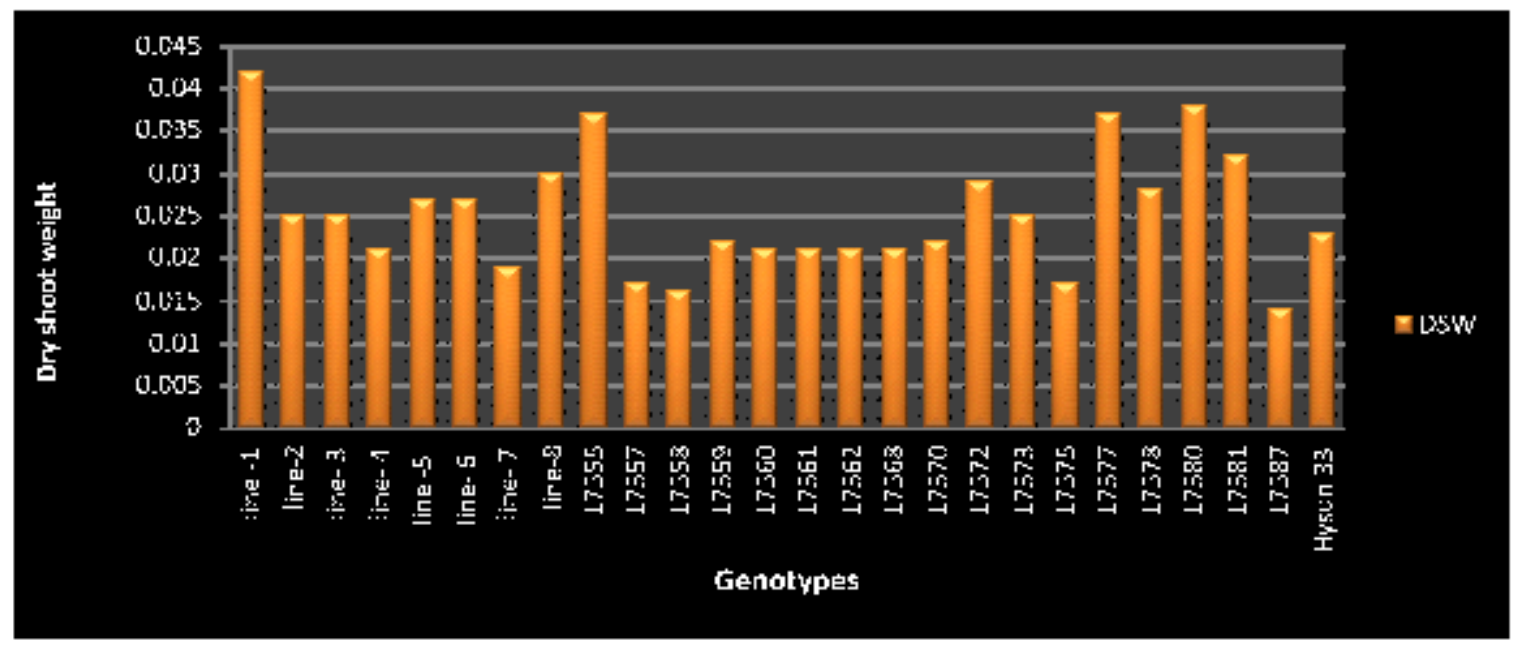

Figure 6: Dry shoot weight in 27 Sunflower Genotypes under Drought stress

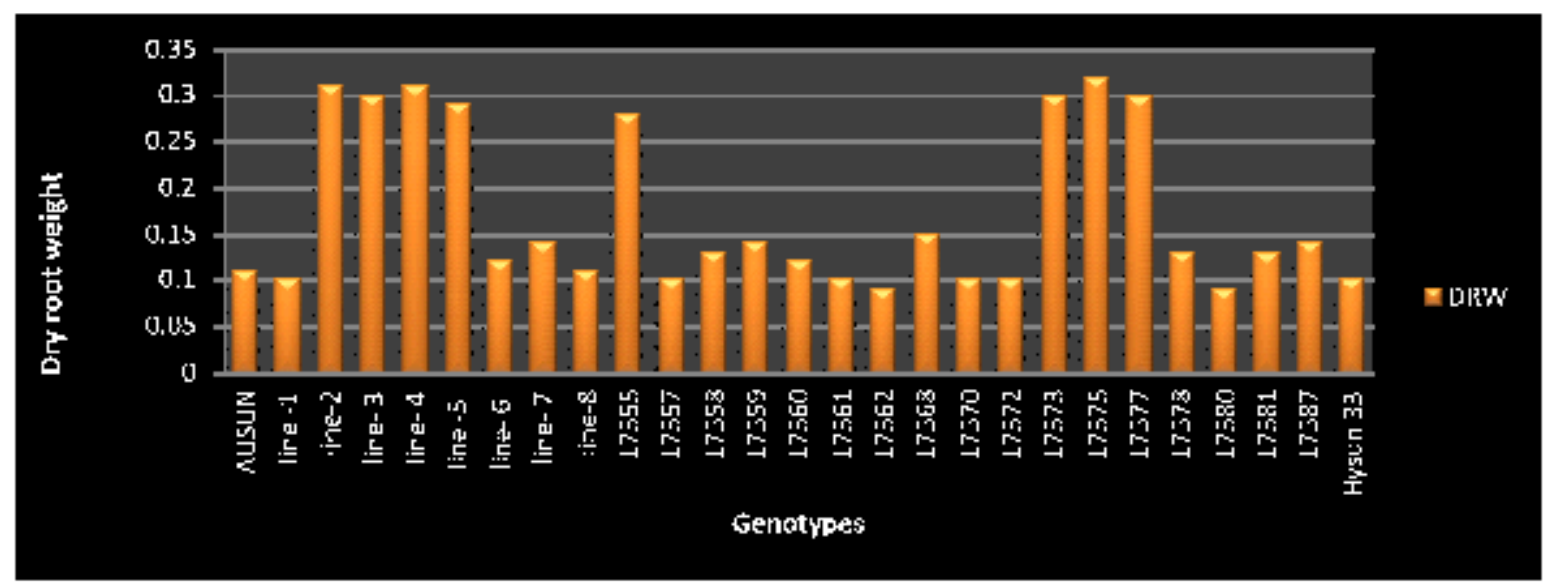

Figure 7: Dry Root weight in 27 Sunflower Genotypes under Drought stress

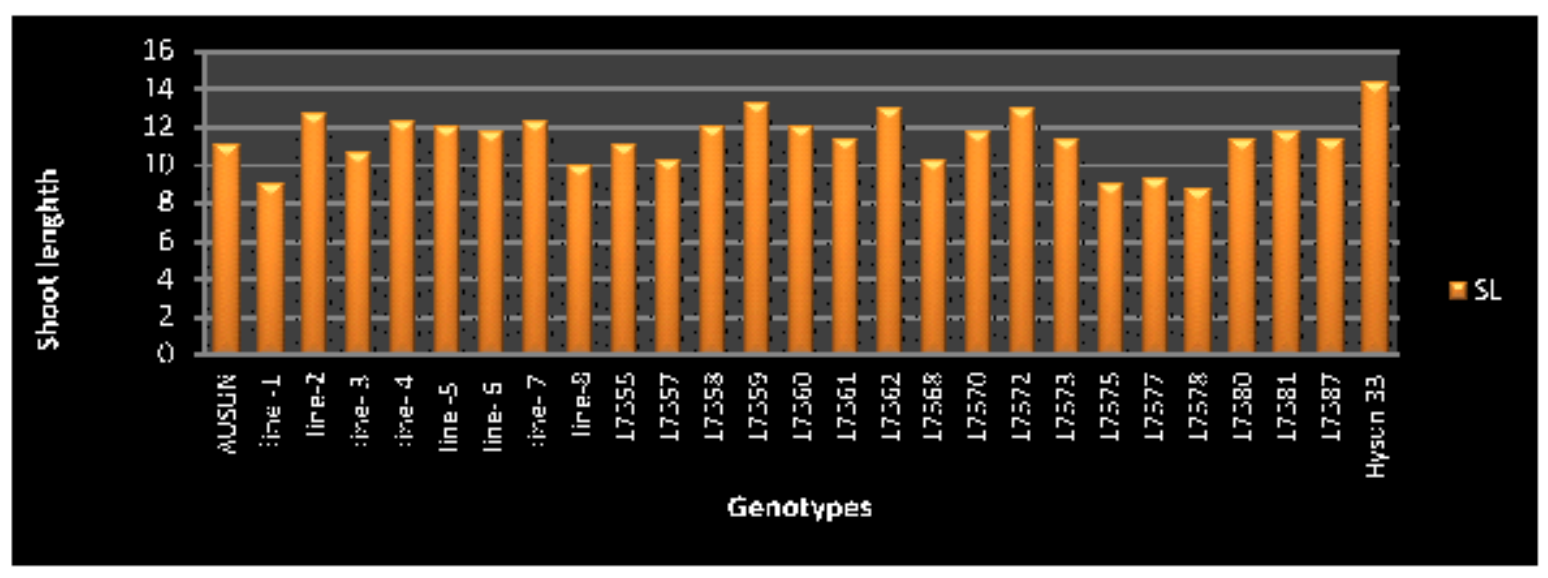

Figure 8: Shoot length in 27 Sunflower Genotypes under Drought stress 


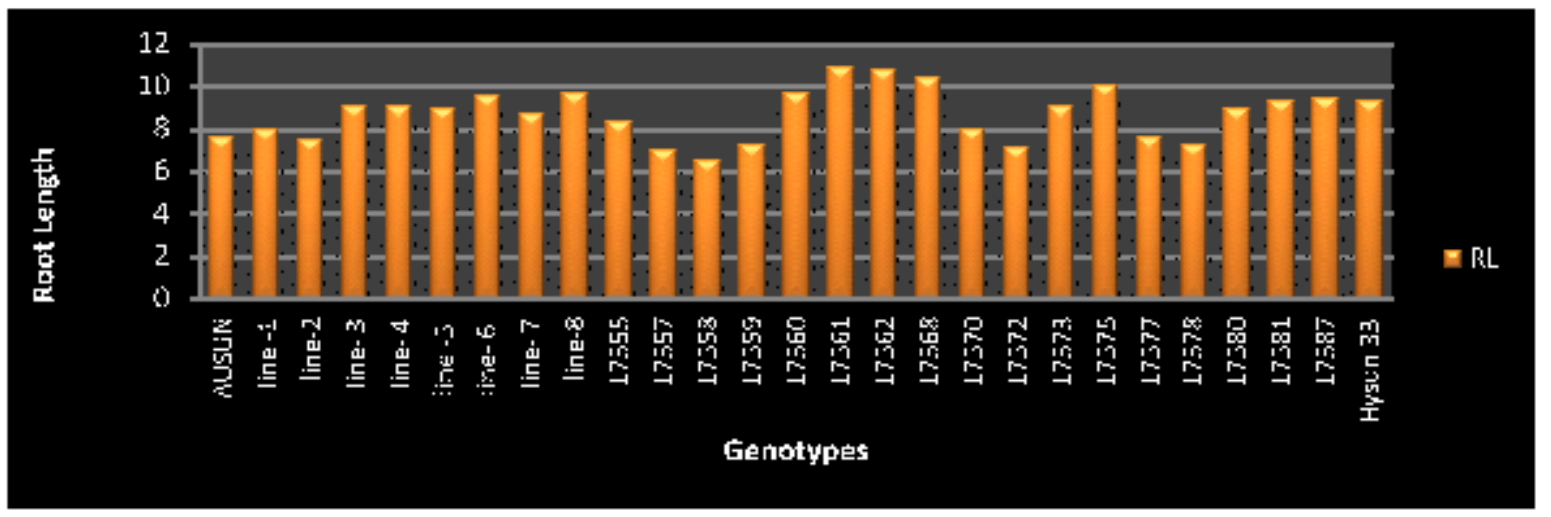

Figure 9: Root Length in 27 Sunflower Genotypes under Drought stress

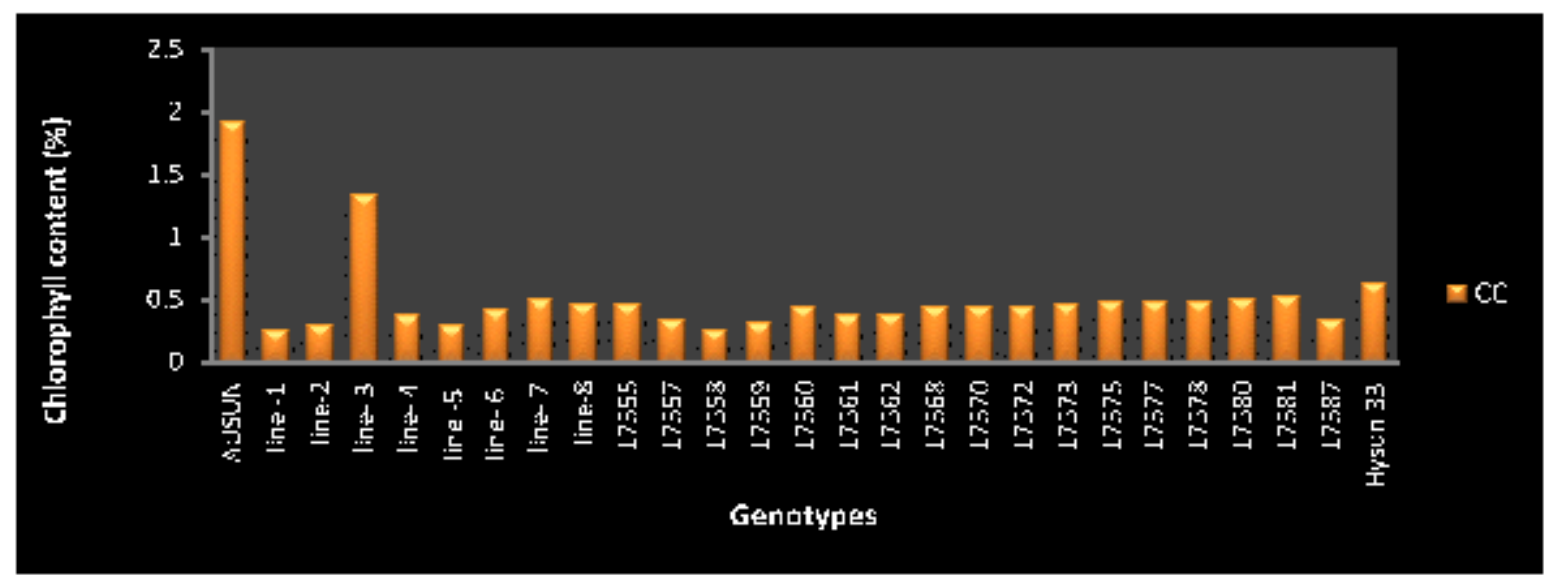

Figure 10: Chlorophyll content in 27 Sunflower Genotypes under Drought stress

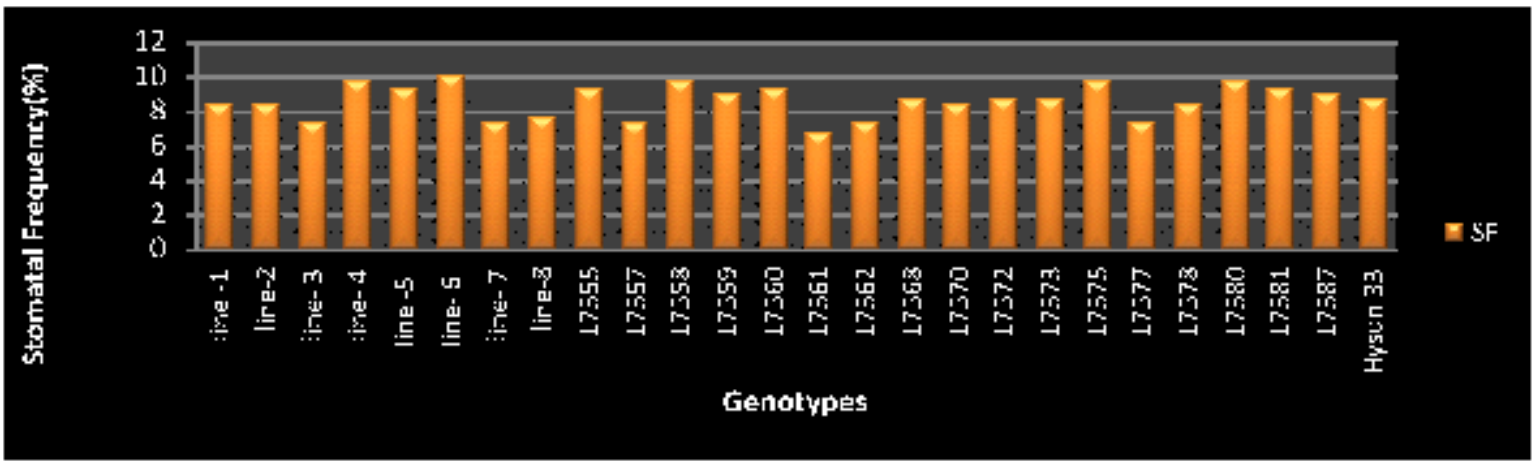

Figure 11: Stomatal Frequency in 27 Sunflower Genotypes under Drought stress

\section{Conclusion}

It was concluded that genotypes Ausun, line-1, line-2, line 3, 17578, 17570, line-6, line-7 and 17562 were diverse among all the genotypes showed resistance against stress will be used in future sunflower breeding programs to produce drought tolerant genotypes. The present analysis relates to Khamsee et al. (2012), Mudassar et al. (2013), Mehdi et al. (2013), Andrea et al. (2013) and Reza et al. (2013) under drought condition.

\section{Acknowledgements}

All the authors contributed equally in sample collection, analysis and presentation of the data. The primary author is especially grateful to Dr.
Muhammad Fareed Khan Dean Faculty of Management Sciences, University of Poonch Rawalakot, Dr.shahid Iqbal Awan and Dr. Muhammad Ilyas Assistant professor Department of Plant Breeding and molecular Genetics Faculty of Agriculture, The University of Poonch Rawalakot Azad Jammu \& Kashmir Pakistan for their moral support.

\section{References}

1. Abdi, N., R. Darvishzadeh, M. Jafari, A. Pirzad and P. Haddadi. (2012) Genetic analysis and QTL mapping of agro-morphological traits in sunflower (Helianthus annuus L.) under two contrasting water treatment conditions. J. Plant. Omics. 5(2):149-158. 
2. Arnon, D. (1949) Copper enzymes in isolated chloroplasts, polyphenoxidase in sugar beet (Beta Vulgaris). Plant. Physiol., 24: $1-15$.

3. Andrea, A., A. Vigliocco, S. Alemano, A. Llanes and G. Abdala. (2013) Comparativeve morpho-biochemical responses of sunflower lines sensitive and tolerant to water stress. Eur. J. Biol., 11(4): 156-167.

4. Hammer, O., D. A. T. Harper and P. D. Rayn. (2001) PAST: Paleontological statistical software package for education and data analysis. Paleontological Electronica. 4(1):9-10.

5. Kumar, R., K. Karajol and G. R. Naik. (2011) Effect of polyethylene glycol induced water stress on physiological and biochemical responses in pigeon Pea (Cajanus cajan L.). Res. Sci. Tech., 3: 148-152.

6. Khamsee, S., T. Machikowa and N. Muangsan. 2012. Comparative performance of sunflower (Helianthus annus L.) synthetic varieties under drought stress. J. Agric. Biol., 14: 29-34.

7. Nadeem, M., F. M. Anjum, M. U. Arshad and S. Hussain. (2011) Chemical characteristics and antioxidant activity of different sunflower hybrids and their utilization in bread. Afric. J. Food Sci., 4(10): 618-626.

8. Mudassar, I., I. Usman, M. Khalid, M. Najeebullah, N. Shahid and A. Hafeez. 2013. Genetic divergence and path coefficient analysis for yield related attributes in sunflower (Helianthus annuus L.) under less water conditions at the productive phase. J. Plant. Know, 2(1): 20-23.
9. Mehdi, G., S. Haji and M. Hoseinlou. (2013) Seed yield determinants of sunflower under drought stressed and well watered conditions. Int. J. Agro. Plant. 4: 3816-3823.

10. Reza, A., B. Kamkar 2, M. Ataei, A.Jaime, T. Silva. (2013) Assessment of the response of sunflower cultivars to water shortage using various stress tolerance indices. J. Intl. Agron., 4(7): 1628-1636.

11. Shamim, A., R. Ahmed, M. Yasin, M. Ashraf and E. Waraich. (2013) Sunflower (Helianthus annus L.) response to drought stress at germination and seedling growth stages. J. Pak. Bot. 41(2): 647654.

12. Snedecor, G. W. (1956) Statistical Methods. 5th edition. Iowa State University Press, Ames, Iowa, U.S.A

13. Sneath, P. H. A and R. R. Shokal. (1973) Numerical Taxonomy: The principles and practices of numerical classification. W. F and Co. Freeman, San Francisco.

14. Tardieu F., R Tuberosa. (2010) Dissection and modelling of abiotic stress tolerance in plants. J. Pl. Biol., 13(2): 206-212.

15. Xia, M. W., H. Ling, J. Ma and D. D. Kitts. (2005) Supplementation of diets with the black rice pigment fraction attenuates atherosclerotic plaque formation in mice. J. Nutr. 133: 744-751.

16. Yosephine, S., Depari. V and Pristantho. F. (2013) Effect of drought stress induced by polyethylene glycol (PEG6000) on callus of(Helianthus annus L.) cv brestagi. J. Applied. Environ. 3(2): 73-78.

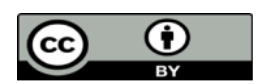

This work is licensed under Creative Commons Attribution 4.0 License

To Submit Your Article Click Here: Submit Article

DOI: $10.31579 / 2692-9562 / 014$
Ready to submit your research? Choose Auctores and benefit from:

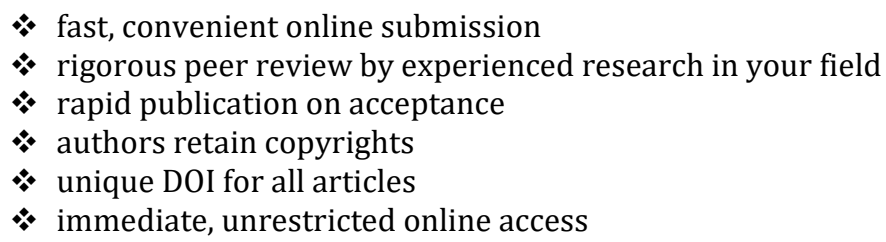

At Auctores, research is always in progress.

Learn more www.auctoresonline.org/journals/biomedical-researchand-clinical-reviews- 